\title{
Comparative study between aspirin to acenocoumarol in regressing spontaneous echo contrast in mitral stenosis
}

\author{
Ali Ghanie
}

\begin{abstract}
Abstrak
Mitral stenosis merupakan kelainan katup yang paling sering ditemukan di bagian Kardiologi RS. M. Hoesin, Palembang, dan bukti kuat menunjukkan adanya tromboemboli pada mitral stenosis. Banyak studi melihat kontras ekho spontan (KES) yang dianggap sebagai awal kejadian tromboemboli, namun terdapat kontroversi mengenai bagaimana mencapai regresi KES ini. Uji klinik tersamar ganda dilakukan untuk membandingkan aspirin $100 \mathrm{mg}$ dengan acenocoumarol (sintrom) $1 \mathrm{mg}$ yang diberikan selama 4 minggu pada 22 penderita mitral stenosis. Pada akhir penelitian diperoleh regresi $100 \%$ pada KES kelompok acenocoumarol, 40\% diantaranya regresi dari KES berat menjadi ringan, sedangkan $60 \%$ mengalami resolusi sempurna. Pada kelompok aspirin tidak satupun KES mengalami regresi. Pada kelompok acenocoumarol, 2 di antara 4 trombus menghilang, sedangkan 2 sisanya ukurannya mengecil, sedangkan pada kelompok aspirin pada akhir minggu keempat, pasien dengan thrombus bertambah dari 3 menjadi 4 . Kesimpulan: Pemakaian acenocoumarol $1 \mathrm{mg}$ selama 4 minggu dapat secara efektif dan aman meregresi kontras echo spontan dan thrombus pada mitral stenosis tanpa perubahan hemodinamik yang berarti. (Med J Indones 2002; 11: 202-7)
\end{abstract}

\begin{abstract}
Mitral stenosis is one of the most often valvular disease in Division of Cardiology, M. Hoesin hospital, Palembang, and there was strong evidence of thromboembolic phenomenon in mitral stenosis (MS) patients. Many studies evaluated the spontaneous echo contrast (SEC) that was regarded as a precursor of thrombo embolic phenomenon. So far there were controversies regarding how to regress spontaneous echo contrast. A randomized double blind controlled study was done on 22 MS patients with positive SEC, receiving either aspirin $100 \mathrm{mg}$ or acenocoumarol $1 \mathrm{mg}$ and followed up after 4 weeks. There was $100 \%$ regression of SEC in acenocoumarol group that consisted of $40 \%$ regression from severe SEC to mild, and $60 \%$ complete resolution. In aspirin group there was no resolution of SEC. In acenocoumarol group, 2 of 4 thrombus totally disappeared while the rest was reduced in size. On the other hand, in aspirin group, after 4 weeks, the patients with thrombus was increased from 3 to 4 patients. In conclusion, four week therapy with acenocoumarol $1 \mathrm{mg}$ is effective and save in regressing spontaneous echo contrast and thrombus in mitral stenosis patients without any significant change in hemodynamics. (Med J Indones 2002; 11: 202-7)
\end{abstract}

Keywords: thrombus, thromboembolic phenomenon, transthoracal, esophageal, echocardiography

In Division of Cardiology, M. Hoesin hospital, Palembang, mitral stenosis (MS) is still one of the most often valvular disease as a sequelae of rheumatic heart disease. Between 1990-1994 in Mohammad Hoesin Hospital, $13.94 \%$ of valvular diseases were MS, in which less than $1 \%$ could afford a balloon mitral valvuloplasty. In addition, in our clinic, almost all young patients with cerebro-thrombo-embolic phenomenon had a MS during echo examination. ${ }^{1}$

Division of Cardiology Department of Internal Medicine, Mohammad Hoesin Hospital / Faculty of Medicine Sriwijaya University, Palembang
According to Deverall, atrial fibrillation (AF) is one of the most often complication of mitral stenosis that happened in $40 \%$ of the patients. The incidence is related to age, and cerebral emboli are particularly common accounting for $60 \%$ to $70 \%$ of episodes of systemic embolism in several reports (cited from Dalen). ${ }^{2}$ Therefore, the presence of AF in MS is a clear indication for long term anticoagulant treatment with a target range of 2-3 International Normalized Ratio (INR).

Feigenbaum was the one who first described the phenomenon of spontaneous echo contrast (SEC). Spontaneous echo contrast is a well described ultrasonographic phenomenon that most commonly 
related to low flow states in cardiac chambers. ${ }^{3}$ Although much has been learned since then, the pathophysiology of SEC is not fully understood. Numerous study indicated that SEC represent a risk factor for the occurrence of thromboembolic events. $^{4,5,6}$

Based on SEC as a risk factor of thrombus formation or thromboembolic phenomenon, we would like to compare aspirin $100 \mathrm{mg}$ to acenocoumarol $1 \mathrm{mg}$ in regressing SEC and thrombus in MS patients.

\section{METHODS}

The design of this study was double blind randomized clinical trial. Population of this study were in and out patients of our clinic at the Department of Cardiology, M. Hoesin hospital, Palembang. Inclusion criteria was patients with mitral stenosis and SEC positive as proved by echocardiography, who came in 1998 (until 20 patients were enrolled in this study), and were willing to participate and to sign the informed consent form. Patients were allocated randomly to group I (aspirin $100 \mathrm{mg}$ ), and group II (acenocoumarol, Sintrom $^{\circledR} 1 \mathrm{mg}$ ).

\section{Echocardiography}

The echo machine used is ATL Cx 200. A $3.5 \mathrm{mHZ}$ tranducer was used for transthoracal echocardiography (TTE), and a multiplane with multifrequency tranducer for transesophageal echocardiography (TEE). Transthoracal echocardiography was performed as a screening for MS. Spontaneous echo contrast, left atrium (LA) diameter, left atrial appendage (LAA) diameter, and ejection fraction, were measured using TEE, and mitral valve area (MVA) was measured using pressure half time (PHT). Spontaneous echo contras was graded as mild if the smoke-like echo did not fill all the LA, and need a gain setting (Fig 1), severe if the smoke-like pattern was dense and well distributed to LA (Fig 2), ${ }^{6}$ and thrombus if a dense echo attached to chamber wall (Fig 3).

Trans-esophageal echocardiography was repeated after 1 month. Echocardiography was performed by single cardiologist expertise, and blinded to the patients.

\section{Statistical analysis}

For continuous variable, student t test was used to compare the 2 groups. 
Figure 2. Severe spontaneous echo contrast (SEC): the dense echo filled almost all the area of LA, and two small thrombus (TH) attached to the posterior wall 


\section{RESULTS}

From 36 MS patients recruited, 22 patients fulfilled the criteria, out of which 1 patient died, and 1 patient got stroke. Finally 10 patients were allocated for aspirin (group I) and 10 patients for acenocoumarol (group II).

Basic demographic data in both groups including gender, age, severity of stenosis, LA size, and left ventricle (LV) size and function were comparable without any significant difference (Table 1).

Table 1. Characteristics of the patients

\begin{tabular}{lccc}
\hline $\begin{array}{c}\text { Echocardio- } \\
\text { graphic } \\
\text { parameter }\end{array}$ & Group I & Group II & $\begin{array}{c}\text { Difference } \\
\text { between } \\
\text { group I and II }\end{array}$ \\
\hline Sex M/F & $4 / 6$ & $1 / 9$ & $\mathrm{NS}$ \\
Ages (years) & 40.70 & 37.60 & $\mathrm{NS}$ \\
AF/NSR & $8 / 2$ & $7 / 3$ & $\mathrm{NS}$ \\
EDD $(\mathrm{cm})$ & 4.44 & 4.45 & $\mathrm{NS}$ \\
ESD $(\mathrm{cm})$ & 2.78 & 2.88 & $\mathrm{NS}$ \\
EF $(\%)$ & 69 & 69 & $\mathrm{NS}$ \\
$\varnothing$ LA $(\mathrm{cm})$ & 4.8 & 4.94 & $\mathrm{NS}$ \\
MVA & 1.03 & 1.01 & $\mathrm{NS}$ \\
Press. gradient & 20.4 & 19.9 & $\mathrm{NS}$ \\
\hline
\end{tabular}

$\mathrm{M}=$ male, $\mathrm{F}=$ female, $\mathrm{AF} / \mathrm{NSR}=$ atrial fibrillation/normal sinus rythm, $\mathrm{EDD}=$ end diastolic diameter, $\mathrm{ESD}=$ end systolic diameter, $\mathrm{EF}=$ ejection fraction, $\varnothing \mathrm{LA}=$ left atrium diameter,

MVA= mitral valve area, Press.=pressure, NS=not significant
There were no significant changes in trans-esophageal echo parameter in group I and II including LA diameter, LAA ejection fraction, MVA and pressure gradient before and after 1 month therapy (Table 2).

Also there were no significant changes in laboratory finding such as $\mathrm{Hb}$, WBC, clotting and bleeding time, and trombocyte count in group I and II after 1 month therapy with aspirin and acenocoumarol (Tabel 3).

In group I, SEC was severe in 8 patients $(80 \%)$, and mild in 2 patients (20\%), while in group II 9 patients $(90 \%)$ had severe SEC, and 1 patient $(10 \%)$ had mild SEC. By TEE thrombus were found in 3 patients $(30 \%)$ in group I, and 4 patients $(40 \%)$ in group II.

After 1 month of therapy, in group I, SEC persisted, which in 8 patients $(80 \%)$ SEC was regarded as severe, and in 2 patients (20\%) as mild. Thrombus also persisted, and the worst, the patients with thrombus increased from $4(40 \%)$ to $5(50 \%)$ in group I.

On the other hand, in group II, SEC disappeared in 5 patients $(50 \%)$, became mild in 4 patients $(40 \%)$, and persisted as having severe SEC in 1 patient $(10 \%)$. Regarding thrombus, 2 patients $(50 \%)$ underwent complete resolution, while in the other two the thrombus were fragmented, one of which belong to the severe SEC that persisted (Table 4).

Table 2. Parameter of TEE before and after treatment

\begin{tabular}{|c|c|c|c|c|c|c|c|c|c|c|}
\hline \multirow{3}{*}{$\begin{array}{c}\text { Echocardiographic } \\
\text { parameter }\end{array}$} & \multicolumn{5}{|c|}{ Group I } & \multicolumn{5}{|c|}{ Group II } \\
\hline & \multicolumn{2}{|c|}{ Before } & \multicolumn{2}{|c|}{ After } & \multirow{2}{*}{$\begin{array}{c}\text { Before } \\
\text { and after } \\
\text { treatment } \\
\text { difference }\end{array}$} & \multicolumn{2}{|c|}{ Before } & \multicolumn{2}{|c|}{ After } & \multirow{2}{*}{$\begin{array}{c}\text { Before anc } \\
\text { after } \\
\text { treatment } \\
\text { difference }\end{array}$} \\
\hline & Mean & SD & Mean & SD & & Mean & SD & Mean & SD & \\
\hline LAA diastolic & 10.59 & 3.74 & 10.2 & 3.65 & NS & 9.13 & 4.68 & 8.75 & 4.02 & NS \\
\hline LAA systolic & 8.19 & 4.17 & 7.45 & 4.24 & NS & 7.02 & 4.60 & 6.79 & 3.60 & NS \\
\hline EF. LAA $(\%)$ & 53.7 & 9.67 & 61 & 8.27 & NS & 54.5 & 13.87 & 53.2 & 13.47 & NS \\
\hline MVA & 1.06 & 0.39 & 1.05 & 0.36 & NS & 0.95 & 0.13 & 0.98 & 0.47 & NS \\
\hline Press. gradient & 21.00 & 2.3 & 20.5 & 2.99 & NS & 19.9 & 2.08 & 20.1 & 1.73 & NS \\
\hline
\end{tabular}

$\mathrm{LAA}=$ left atrial appendage, EF.LAA=ejection fraction of left atrial appendage, $\mathrm{MVA}=$ mitral vakve area, Press.= pressure, $\mathrm{NS}=$ not significant, $\mathrm{SD}=$ standard deviation 
Table 3. Laboratory results of both groups

\begin{tabular}{|c|c|c|c|c|c|c|c|c|c|c|}
\hline & \multicolumn{5}{|c|}{ Group I $(n=10)$} & \multicolumn{5}{|c|}{ Group II $(n=10)$} \\
\hline & \multicolumn{2}{|c|}{ Before } & \multicolumn{2}{|c|}{ After } & \multirow{2}{*}{$\begin{array}{c}\text { Before } \\
\text { and after } \\
\text { treatment } \\
\text { difference }\end{array}$} & \multicolumn{2}{|c|}{ Before } & \multicolumn{2}{|c|}{ After } & \multirow{2}{*}{$\begin{array}{c}\text { Before } \\
\text { and after } \\
\text { treatment } \\
\text { difference }\end{array}$} \\
\hline & Mean & $\mathrm{SD}$ & Mean & SD & & Mean & SD & Mean & SD & \\
\hline $\mathrm{Hb}$ & 13.34 & 0.65 & 13.0 & 0.72 & NS & 12.86 & 1.01 & 12.74 & 0.97 & NS \\
\hline WBC & 7640 & 1018.0 & 7180 & 1043.0 & NS & 6740 & 1147.17 & 6510 & 976.89 & NS \\
\hline Clotting Time & 12.9 & 0.64 & 13.11 & 0.56 & NS & 13.31 & 0.54 & 13.24 & 0.31 & NS \\
\hline Bleeding Time & 2.86 & 0.40 & 2.94 & 0.34 & NS & 2.61 & 0.37 & 2.6 & 0.29 & NS \\
\hline Thrombosit & 200.50 & 17.39 & 195.4 & 17.91 & NS & 202.50 & 13.32 & 191.70 & 16.47 & NS \\
\hline
\end{tabular}

$\mathrm{Hb}=$ hemoglobin, $\mathrm{WBC}=$ white blood cell count, $\mathrm{NS}=$ not significant, $\mathrm{SD}=$ standard deviation

Table 4. Treatment effects on SEC and thrombus in both group

\begin{tabular}{lcccc}
\hline \multicolumn{1}{c}{$\begin{array}{c}\text { Echocardiographic } \\
\text { parameter }\end{array}$} & Group I (n=10) & Group II (n=10) \\
& $\begin{array}{c}\text { Before } \\
\mathrm{n}(\%)\end{array}$ & $\begin{array}{c}\text { After } \\
\mathrm{n}(\%)\end{array}$ & $\begin{array}{c}\text { Before } \\
\mathrm{n}(\%)\end{array}$ & $\begin{array}{c}\text { After } \\
\mathrm{n}(\%)\end{array}$ \\
\hline SEC & $10(100 \%)$ & $10(100 \%)$ & $10(100 \%)$ & $5(50 \%)$ \\
Mild SEC & $1(10 \%)$ & $2(20 \%)$ & $1(10 \%)$ & $4(40 \%)$ \\
Severe SEC & $9(90 \%)$ & $8(80 \%)$ & $9(90 \%)$ & $1(10 \%)$ \\
& & & $4(40 \%)$ & $2(20 \%)$ \\
Thrombus & $3(30 \%)$ & $4(40 \%)$ & - & $2(20 \%)$ \\
Disappear & - & - & $20 \%)$ \\
Fragmented & & & \\
\hline
\end{tabular}

$\mathrm{SEC}=$ spontaneous echo contras

\section{DISCUSION}

Spontaneus echo contrast is dynamic smoke-like echo that hypothetically caused by some factors such as stasis of blood in left atrium particularly in atrial fibrillation and mitral stenosis. ${ }^{4,5,6}$ Another factor to predict flow is LAA ejection fraction, because it can tell the flow velocity in LA and LAA. ${ }^{7,8}$ Other hypothesis mentioned the role of erythrocyte rouleaux formation. ${ }^{9}$ In addition, a study found an association between erythrocyte sedimentation rate and low shear blood viscosity, supporting a role of red cell aggregation in SEC formation. ${ }^{10}$ Both red cells interaction and plasma protein at low flow and low shear condition were required to produce echogenic smoke. ${ }^{11}$
In our study there was no significant difference in the echo parameters before and after intervention in both groups. Atrial fibrillation and left atrial size is also one of the factors related to SEC formation, ${ }^{4,5}$ but again in this study there were no significant changes in those parameters after treatment compared to before treatment.

Due to limitation in our laboratory to check all hemostasis parameters and our study is beyond the pathophysiologic aspect, we only look at the trombocyte count, and bleeding and clotting time. Those parameters didn't change after intervention. In this study, $1 \mathrm{mg}$ acenocoumarol showed no bleeding that was one of the harmfull side effects and limitations in using anticoagulant. These findings couldn't explain the regression of SEC in group II. So 
far, there was no study supporting the effect of acenocoumarol on resolution of SEC, but as anti coagulant it did impede progression from red cell aggregation to thrombus formation, or it might have a role in platelet aggregation.

Fatkin et $\mathrm{al}^{12}$ showed that plasma protein mediated red cell aggregation was one of the mechanism of SEC in human. Therefore, they suggested to directly inhibit red cell aggregation to provide an alternative way in reducing thromboembolic risk. Another study using sodium warfarin on one patient who had a thrombus in LAA and SEC in LA, showed that after 2 months there were resolution of the thrombus but not the SEC. ${ }^{5}$ Mahony reported one case of SEC in which complete resolution of SEC happened after a 5-day treatment with trifluoperazine (a platelet disaggregator). ${ }^{13}$ In addition, other study from Kearny and Mahony looked at the effect of aspirin on SEC in brachial veins of normal subjects; they concluded that aspirin $650 \mathrm{mg}$ twice daily could reduce platelet aggregation score, that was an aspirin sensitive component of SEC. ${ }^{14}$ In our study, there were no resolution at all in the aspirin group. This might be due to the dosage that was too small compared to the study by Kearny and Mahony.

In conclusion, spontaneous echo contras in mitral stenosis patients should be considered as a risk factor for thrombus formation, and should be treated to prevent thrombus formation. One $\mathrm{mg}$ of acenocoumarol is quite effective in regressing SEC and save without side effect (bleeding). Further study with more specific design are required to look at the role of anti-coagulant in regressing spontaneous echo contrast in mitral stenosis patient.

\section{Aknowledgment}

The author thanks Drs. Junaidi, and M. Diah who kindly prepared the patients, and Prof.Dr.Jahya Kisjanto and Prof.Dr.Karmel Tambunan for their valuable advice in the revision of this article.

\section{REFERENCES}

1. Ghanie A. Profile of cardiac cases in General Hospital Palembang 1990-1994 (unpublished data).

2. Dalen JE. Mitral stenosis in valvular heart disease. $3^{\text {rd }}$ edition. Philadelphia: Lippincott Williams \& Wilkins, 2000.p.83-4.

3. Feigenbaum. Ecchocardiography. $2^{\text {nd }}$ edition. Philadelphia: Lea and Febiger, 1994.p.48

4. Daniel GW. Left atrial spontaneous echo contrast in mitral valve disease: An indicator for an increased thromboembolic risk. JACC 1998; 11(6):1204-11.

5. Castello R. Prevalence and clinical implications of atrial spontaneous contrast in patient undergoing transesophageal echocardiography. Am J Cardiol 1990; 65:1149-53.

6. Black IW. Left atrial spontaneous echo contrast : A clinical and echocardiographic analysis. JACC 1991; 18(2):398-404

7. Yi-HL. Left atrial spontaneous echo contrast in patients with rheumatic mitral valve disease in sinus rhytm. Chest 1995;108:99-103.

8. GarciaFernandes MA. Left atrial appendage Doppler flow pattern: Implication on thrombus formation. Am Heart $\mathbf{J}$ 1992;124:955.

9. Xin-FW. The relationship between intracardiovascular smoke-like echo and erythrocyte rouleaux formation. Am Heart J 1992; 124(4): 961-5.

10. Fatkin D. Hematologic correlates of spontaneous echo contrast in patients with atrial fibrillation and implications for thromboembolic risk, Am J Cardiol 1994; 73:672-6.

11. Merino A. Echocardiographic "Smoke" is produced by an interaction of erythrocytes and plasma proteins modulated by shear forces. JACC 1992;20(7):1661-8.

12. Fatkin D. Inhibition of red cell anggregation prevents spontaneous echocardiographic contrast formation in human blood. Circulation 1997; 96(3):889-96.

13. Mahony C. Resolution of sponraneous contras with platelet disaggregatory therapy (Trifluoperazine). Am J Cardiol 1989;63:1009-10.

14. Kearny K, Mahony C. Effect of aspirin on spontaneous echo contrast in the brachial veins of normal subjects. Am J Cardiol 1995;75:924-8. 